\title{
PENGARUH KECAKAPAN MEDIA (MEDIA LITERACY) TERHADAP TERBANGUNNYA KEWARGAAN AKTIF (ACTIVE CITIZENSHIP) (STUDI PADA SISWA SMA WIDYAGAMA DAN SMKN 4 KOTA MALANG)
}

\author{
Priyo Dari Molyo \\ priyodarimolyo@unmer.ac.id \\ Program Studi Ilmu Komunikasi FISIP Universitas Merdeka Malang
}

\begin{abstract}
Abstrak
Media diidealkan sebagai pillar keempat penyangga proses demokratisasi lewat sajian informasi yang objektif, netral dan berimbang. Namun, media tidak pernah beroperasi dalam ruang hampa dalam melaksanakan fungsi tersebut. Media selalu bekerja dengan dorongan ekonomi, politik dan ideologis sekaligus. Hal ini jelas akan menghambat proses demokratisasi. Pada saat yang bersamaan, media juga telah menyatupadu dan tidak terpisahkan dari kehidupan masyarakat. Kecakapan mengkonsumsi media (media literacy) yang mencakup kemampuan mengakses, menganalisis, mengevaluasi, dan mencipta ragam ekspresi menjadi prasyarat penting dalam dunia yang sarat dengan pesan komunikasi multi media ini. Kemampuan yang bermuara pada diperolehnya ketrampilan berpikir kritis (critical thinking) serta kecakapan mengungkapkan diri (self expression) ini mendesak untuk dimiliki oleh setiap warga agar mereka dapat terlibat secara aktif dalam proses pembuatan keputusan negara yang strategis yang berdampak signifikan terhadap kehidupan mereka. Kewargaan aktif (active citizenship) yang merupakan akibat dari proses pendidikan media merupakan hal strategis untuk mengawal kehidupan demokrasi. Tulisan yang mengkaji pengaruh media literasi terhadap terbentuknya kewargaan aktif ini dilaksanakan di SMA Widyagama dan SMKN 4 Kota Malang. Menggunakan metode survei dengan responden kelas XI pada kedua sekolah, penelitian ini menemukan kuatnya pengaruh media literacy terhadap kewargaan aktif.
\end{abstract}

Kata Kunci: Media Literacy, Kewargaan Aktif, Spiral Pemberdayaan, Pendidikan Kewargaan,

\begin{abstract}
Media function as the fourth pillar of democracy when they cover and present news in an objective, neutral, and balanced manner. Nevertheles, media never operated in vacuum in carrying out the duties. Neither, media did so purely to serve public interest. But, media did the the job to serve certain economic and political interest simultenously. This of course will block the way for the current undergoing democratization process. To make the case even worse, media become an integral part of the society life in which they were saturated by media industry. As such, media literacy which equipped citizens which skills such as access, analysis, evaluation, and creation played a strategic role to empower citizen to actively take part in their social and political life. This is due to the fact that through media literacy citizen will acquire critical thinking and self expression skills which are necessary requirement to be active citizen. This article attempts to explore the influence of media literacy on active
\end{abstract}


citizenship among student of Widya Gama private-owned and State Senior High Vocational School IV Malang City. Employing quantitative survey method, the research found a great impact of media literacy on active citizenship among grade two of the above said school students.

Key Word: Media Literacy, Active Citizenship, Spiral of Empowerment, Civie Education.

Pendahuluan.

Angin segar kebebasan berekspresi yang sedang berhembus dan dinikmati masyarakat dan pers nasional merupakan buah perjuangan panjang dari reformasi. Kebebasan berpendapat yang merupakan salah satu aspek Hak Asasi Manusia (HAM) ini mutlak diperlukan bagi tercapainya sebuah tatanan kehidupan bernegara yang demokratis untuk mewujudkan sebuah masyarakat yang sejahtera lahir batin dan berkeadilan sosial. Untuk menggapai citacita ini, pers sebagai agen informasi, pendidikan, hiburan dan kontrol sosial memiliki peran strategis untuk membantu mewujudkan hal tersebut. Melalui fungsi kontrol sosialnya, pers dapat memonitor dan mengawasi setiap perilaku penguasa, pengusaha dan masyarakat yang menyimpang dari kepentingan rakyat sehingga terjadi keseimbangan (check \& balances) dalam kehidupan bernegara. Sebagai lembaga sosial, media, makanya, seringkali dijuluki sebagai pilar keempat demokrasi (the fourth estate of democracy) yang memiliki tugas utama sebagai watchdog untuk mengawasi dan mempertahan proses demokrasi. Hal ini dapat dilakukan dengan mememenuhi hak warga masyarakat untuk tahu (the rights to know) lewat liputan peristiwa sosial politik yang objektif, netral dan berimbang. Di samping itu, dengan memberikan ruang dan waktu bagi warga untuk berekspresi (the rights to expression).

Meski demikian, posisi pers sebagai lembaga ekonomi mengundang kerawanan terhadap 'godaan' penyimpangan untuk lebih mengutamakan kepentingan sempitnya (politik dan ekonomi) yang secara perlahan akan kian menjauhkan kinerja pers dari kepentingan rakyat. Bahkan media juga bertindak sebagai aktor politik yang berusaha memenuhi kepentingan sempit politiknya untuk meraih kekuasaan tertentu. Kebebasan berpendapat yang telah dinikmati pers nasional, makanya bisa saja diselewengkan untuk memenuhi kepentingan perusahaan pers yang bersangkutan. Untuk itu, diperlukan pilar kelima demi menegakkan 
kehidupan demokrasi, yakni masyarakat sipil yang cerdas dan kritis dalam mengkonsumsi produk pers. Dengan kata lain, peran serta masyarakat mutlak diperlukan demi memelihara kebebasan berpendapat pers ini sehingga kinerja pers nasional benar-benar berjalan sesuai dengan amanat UU Pers dan UU Penyiaran.

Mengingat strategisnnya peran serta masyarakat dalam menjaga kebebasan pers, kedua UU tersebut mendorong masyarakat untuk terlibat aktif memantau kinerja pers agar mereka terhindar dari tindakan pers yang merugikan kepentingan mereka. Peran sera masyarakat ini dapat diakomodasi dalam bentuk pengawasan atas kinerja pers dengan mendirikan lembaga pemantau pers (media watch) . Ini tercantum dalam pasal 17 ayat 1 dan 2 UU No 40 tahun 1999 Tentang Pers dan pasal 52 ayat 1 , dan 2 point a dan b. Hal yang sama juga diakui dalam UU No 32 Tahun 2002 Tentang Penyiaran pada pasal 52 ayat 1,2, dan 3 yang memberikan peluang kepada Organisasi nirlaba, lembaga swadaya masyarakat, perguruan tinggi, dan kalangan pendidikan, dapat mengembangkan kegiatan literasi dan/atau pemantauan Lembaga Penyiaran. Peran serta masyarakat ini dapat diartikan kecerdasan mengkonsumsi isi media (media literacy) yang memungkinkan masyarakat untuk mampu memahami, menganalisa proses produksi teks, membangun realitas media beserta aspek sosial, politik, ekonomi etis dan legal yang menyertai proses tersebut. Dengan bekal ketrampilan ini, diharapkan warga masyarakat mampu memilah dan memilih jenis informasi yang tersuguhkan di media yang akan membantu mereka membuat keputusan yang tepat dalam melakukan sebagai warga negara.

Berdasarkan hal tersebut diatas, partisipasi warga yang terwadahi dalam kegiatan meningkatkan kecakapan media (media literacy) mutlak diperlukan agar mereka menjadi warga negara yang aktif (active citizenship) dalam rangka mengawal proses demokrasi bangsa yang sedang berjalan saat ini. Artikel ini mengkaji pengaruh media literacy terhadap terbentkuknya kewargaan aktif. Tulisan ini disusun dengan membahas relasi media dengan aktivitas politik, ekonomi politik media, konsep media literacy dan kewargaan aktif. Kemudian dilanjutkan dengan memaparkan metode penelitian, pembahasan temuan penelitian dan ditutup dengan simpulan.

\section{Tinjauan Pustaka}

\section{Media dan Demokrasi}

Lokus fungsi demokratisasi pers terletak pada sejauhmana pers telah mampu menjadi sebuah ruang publik (public sphere) 
; sebuah ruang yang terbebas dari dominasi politik penguasa dan kepentingan ekonomi pengusaha yang memungkinkan terjadi perbincangan publik yang rasional tentang isu-isu publik yang mempengaruhi kehidupan masyarakat. Ruang ini menurut Brian Mc Nair (1999;20-21) merupakan esensi lembaga komunikasi substansial masyarakat yang memungkinkan disebarluaskannya fakta dan pendapat. Di ruang yang terdiri dari stok pengetahuan publik ini dapat dibangun dasar tindakan politik kolektif masyarakat. Pada ruang ini pula, menurut Croteau (2001: 20) dimungkinkan dibentuknya sebuah ruang sosial untuk terjadinya perbincangan publik secara bebas tanpa pembatasan. Sebagai ruang publik masyarakat, maka jurnalisme hadir untuk membangun kewargaan (citizenship); untuk memenuhi hak-hak warga sebab jutaan orang terberdayakan oleh arus informasi bebas. Lebih lanjut, Bill Kovach dan Tom Rosenstiel (2004:6) menyatakan bahwa tugas utama wartawan yakni menyediakan informasi yang dibutuhkan warga agar mereka bisa hidup merdeka dan mengatur diri mereka. Agar tugas mulia ini bisa dilakukan wartawan, Bill Kovach menyarankan sembilan hal yang mesti dipegang teguh dalam melaksanakan kegiatan jurnalistik mereka. Sembilan hal tersebut adalah: (1) Kewajiban pertama jurnalisme adalah pada kebenaran; (2)
Loyalitas pertama jurnalisme adalah memenuhi hak mengetahui warga; (3) Intisari jurnalisme adalah disiplin dalam verifikasi; (4) Para wartawan harus menjaga independensi terhadap sumber berita;(5) Jurnalisme harus berfungsi sebagai pemantau kekuasaan; (6) Jurnalisme harus menyediakan forum publik untuk kritik maupun dukungan warga. (7) Jurnalisme harus berupaya membuat hal-hal penting menarik dan relevan; (8) Jurnalisme harus menjaga agar berita komprehensif dan proporsional; (9) Para praktisinya harus diperbolehkan mengikuti nurani mereka;

Dengan nada sama, Mc Nair (1999: 26) menyatakan demokrasi mengasumsikan adanya sebuah sistem yang terbuka yang memungkinkan warga untuk berpartisipasi. Untuk itu mereka harus diberikan akses yang memadai terhadap media dan jaringan informasi yang memungkinkan terjadinya advokasi. Demokrasi juga mengasumsikan khalayak dididik dan diberi pengetahuan yang cukup sehingga mereka dapat membuat keputusan rasional dan secara efektif menggunakan informasi yang tersebarluaskan dalam ruang publik. Lebih lanjut Mc Nair (1999: 21) mengajukan beberapa persyaratan yang harus dipenuhi media demi memperlancara proses demokratisasi. Hal tersebut adalah ; (a) Memberikan informasi kepada masyarakat 
tentang peristiwa yang terjadi di sekitar mereka; (b) Mendidik warga tentang arti dan nilai penting dari fakta lewat tetap menjaga objektivitas peristiwa yang diliput sebagai konsekwensi dari fungsi pendidik yang meniscayakan kemandirian profesional dari isu yang sedang diangkat; (c) Menyediakan sebuah platform bagi terlaksananya sebuah perbincangan publik tentang politik, mempermudah terbentuknya pendapat umum serta menyebarluaskan opini publik tersebut; (d) Mengaplikasikan fungsi sebagai anjing penjaga (watchdog role) dengan mempublikasikan kinerja lembaga politik dan pemerintah dengan melakukan investigasi terhadap penyimpangan yang dilakukan. Opini publik hanya akan bermakna dalam realitas politik ketika perilaku para penyelenggara kekuasaan diungkap kepada publik sehingga publik dapat menuntut pertanggungjawaban; (e) Berfungsi sebagai saluran untuk advokasi pendapat politik tertentu.

Di samping program sinetron, para remaja masih dibombardir dengan tayangantayangan reality show yang ingin memperlihatkan penderitaan, keluguan, dan kelemahan manusia sebagai ajang tontonan (spectacle). Program ini mengajarkan penonton untuk menikmati dan mengganggapnya menghibur atau bahkan lucu dengan melihat orang lain panic, lemah dan bingung. Substansi yang diangkat tayangan acara ini, menurut Grace Swestin (Media Watch, edisi 39-Tahun IV-Agustus 2004) ingin mendepankan kebohongan, uang, seks dan mistik. Singkat kata, ajaran yang diusung acara tersebut adalah : (a) Berbohong dan berkhianat akan membuat seseorang mencapai kesuksesan ("Suvivor", Idosiar); (b) Uang adalah alat utama mendapatkan pasangan ("Joe Millionaire" dan "For Love Or Money" di TV 7); (c) Komunikasi terbuka dan trust antara pasangan tidak penting sehingga perlu penyelidikan untuk mengetahui kesetiaan pasangan ("Harap-Harap Cemas", dan "Playboy Kabel" di SCTV); (d) Mengajari masyarakat untuk bermimpi tentang kekayaan dan mengeksploitasi aksi konsumerisme ("Uang Kaget" di RCTI); (e) Membohongi orang dan membuat orang lain shock itu menghibur ("Emosi", "Paranoid", "Scare Tactics" di Trans TV); (f) Menghalalkan segala cara untuk mendapatkan uang ("MTV's I Bet You Will" di Global TV) bahkan sampai membayakan nyawa dan melakukan hal-hal yang menjijikkan ("Fear Factor" di RCTI); (g) Kecenderungan ke arah voyeurism, mengintip dan menampilkan adegan intim di depan banyak orang, dalam hal penonton televise ("The Bachelor", "The Bachelorette" dan ajang pemilihan jodoh lainnya); (h) Berkencan dengan berganti- 
ganti pasangan ("Temptation Island" di Trans TV); (i) Mahluk gaib ada dimanamana, perlu diperhatikan dengan memberikan sajian ( "Gentanyangan" di TPI, "Percaya Nggak Percaya" di AN TV, "Dunia Lain" di Trans TV).

Hal di atas menyiratkan gejala baru dalam industri media, yakni konsolidasi dan globalisasi. Fenomena konsolidasi dan globalisasi bisnis media merupakan tuntutan meningkatkan keuntungan. Meski fenomena ini diperbolehkan UU No 32 Tahun 2002 Tentang Penyiaran yang memungkinkan masuknya modal asing sebesar 20 persen saham dalam stasiun televisi nasional, tapi hal ini juga dikhawatirkan akan mengancam proses demokrasi yang sedang berjalan. Hal ini mengingat media bukan sekedar lalu lintas pesan semata tapi ia juga merupakan perangkat hegemonik untuk memaksakan konsensus serta memenuhi kepentingan ideologis kelas ekonomi dan politik yang dominan. Kehadiran mereka juga kian meramaikan ruang gelombang frekwensi nasional yang merupakan sumber daya yang terbatas yang makanya menurut UUD 1945 harus dimanfaatkan sebesar-besarnya untuk kesejahteraan rakyat. "Kita saling menggabungkan kekuatan sekarang ini atau kita dapat saling membunuh satu sama lainnya lalu bergabung membentuk kekuatan baru, "demikian tegas Robert Mc Chesney (1997:27).

Media sebagai wahana demokrasi, dengan demikian, tak ubahnya sebuah sarana untuk melanggengkan kcpentingan bisnis media dan sarana menangguk keuntungan belaka. Idealisme pers nasional sebagai tiang penyanggah demokrasi (the fourth pillar of democracy) makanya akan sulit terwujud dalam setting yang tunduk pada rezim pasar. Kepentingan publik pada informasi yang akurat, netral dan berimbang yang bertujuan untuk mencerdaskan dan mencerahkan warga negara (citizen) lenyap begitu saja ditelan hingar-bingar mesin-mesin raksasa kapitalis media. Demikian juga dengan fungsi kontrol sosial pers yang bermuara pada pangawasan terhadap penguasa politik dan pengusaha ekonomi akan kian melemah oleh menguatnya daya dorong memenuhi ekonomi politik media kapitalis. Dengan kata lain, liberalisasi media akan mengubah karakter jurnalistik dan substansi isi ke arah meraup kepentingan ekonomi pasar. Kinerja media, menurut Croteau (2001: 20) akan semakin menjauh dari melayani dan memenuhi kepentingan publik sebab semua operasional media tidak dikelola sebagai sebagai ruang publik (public sphere); sebuah sosial yang memungkinkan terjadinya perdebatan public. Menurut Croteau (2001:37), media massa sekarang 
menempatkan public atau audience sematamata sebagai konsumen bukan warga negara (citizens). Tujuan utama media adalah to generate profit for owners and stockholders. Kemudian mendorong khalayak untuk to enjoy themselves, view ads, and buy product. Karena itu apa yang dianggap menarik bagi oleh media, adalah apapun yang populer di masyarakat. Dengan demikian tujuan ideal media untuk menggairahkan to promote active citizenship via information, education and social integration tenggelam dengan gelombang komersialisasi dan liberalisasi. Makanya, ukuran keberhasilan media semata-mata adalah meraup keuntungan ekonomi, bukan melayani dan memenuhi kepentingan public (serving the public interest).

Akibat langsung dari komersialisasi media adalah melemahnya proses proses demokrasi serta kian tidak berdayanya masyarakat secara politik seperti yang disebut Herbert J Gans $(2003 ; 15)$ sebagai political disempowerment. Hal ini karena pasar, lanjut Croteau (2001: 21-23) memiliki beberapa kelemahan. Pertama, pasar tidak demokratis sebab pasar tidak sesuai dengan asumsi dasar demokrasi bahwa individu memiliki hak-hak yang sama. Padahal hukum pasar adalah "the more money you have, the more influence you have in the marketplace". Kedua, pasar akan akan semakin melanggengkan ketimpangan sosial. Ketiga, pasar tidak bermoral sebab kepentingan utamanya adalah menjual dan memenuhi tuntutan tanpa mempedulikan apakah adakah produk tersebut bermanfaat dan berbahaya terhadap masyarakat. Keempat, pasar tidak selamanya bisa memenuhi kepentingan sosial. Kelima, pasar tidak mampu memenuhi kepentingan demokrasi.

Media literacy (kecakapan bermedia), makanya mendesak untuk dimiliki setiap warga mengingat media massa telah menyatu dengan setiap menit dan detik kehidupan masyarakat. Media, makanya, tidak hanya membentuk budaya masyarakat. Tapi media itu sendiri telah menjadi budaya masyarakat akibat hebat dan 'canggihnya' pesan-pesan yang disasarkan sehingga membuat mereka secara 'suka rela' untuk 'tunduk patuh' kepada kepada rayuan komodifikasi media. Kekuatan hegemonic ini tidak heran kemudian melahirkan "kesadaran palsu" ("false consciousness") pada benak khalayak. Dalam keadaan seperti ini, khalayak tak ubahnya telah menjadi menjadi "buruh" media, walau mungkin dia merasa dirinya bahagia secara semu dalam posisi "penikmat media". Media Literacy (kecakapan bermedia) merupakan sebuah kesadaran dan kecakapan komprehensif, untuk menempatkan diri individu dan masyarakat 
di depan media sebagai pelaku yang aktif. Dengan kecakapan ini, seseorang diharapkan dapat melakukan seleksi terhadap media atau isi media yang ingin dikonsumsinya. Termasuk dalam kecakapan ini adalah pemahaman tentang aspek etika dan regulasi, pengetahuan tentang proses produksi isi media, atau konstruksi social industri media dengan kepentingan politik dan ideologi di belakangnya. Dengan kata lain, buruknya ketrampilan khalayak dalam `membaca' teksteks media, kian memperlemah posisi mereka saat berhadapan dengan tampilan media. Kebutaan mereka terhadap aspekaspek produksi , pengemasan dan penyuguhan teks-teks media menjadikan para para kapitalis media kian 'garang' dan 'liar' dalam memangsa mereka yang berakibat pada jatuhnya korban. (Effendi Gazali. Et al: 2004: 156).

Media massa nasional saat ini memang telah menikmati kebebasan berekspresi yang bertujuan utama untuk untuk mengawal proses demokratisasi bangsa. Sebagai lembaga sosial dan penyangga pilar demokrasi keempat, media berfungsi untuk mengontrol perilaku politik penguasa dan kuasa ekonomi pengusaha. Namun sebagai lembaga ekonomi, media dikelola untuk melayani kepentingan ekonomi politiknya sendiri. Media, makanya, tidak dikelola dalam ruang hampa; media dijalankan dengan dorongan dan motivasi untuk melayani kepentingan ekonomi dan politiknya sendiri agar tetap dapat bertahan hidup. Isi media dan realitas media, makanya bukan merupakan pantulan jujur dari realitas sosial tapi adalah konstruksi dan bentukan dan para pekerja media. Kinerja media, makanya, terkadang bisa beriringan dengan kepentingan publik. Tapi bisa juga bisa berseberangan dengan kepentingan ideal tersebut. Kalau demikian adanya maka proses demokratisasi bangsa yang merupakan kewajiban etik media untuk memeliharanya akan terhambat. Untuk itulah diperlukan pilar kelima demokrasi, yakni masyarakt sipil yang memiliki kecakapan media. Lewat ketrampilan media yang bermuara pada pada terbentuknya daya pikir kritis (critical thinking) dan kemampuan mengungkapkan diri (self expression) ini akan bisa mendorong terbangunnya kewargaan aktif (active citizenship) yang akan mendorong mereka ikut terlibat aktif dalam menjaga proses demokrasi. Lewat dua ketrampilan tersebut, warga diharapkan akan mampu memilih informasi politik, serta memahami dan mengambil peran aktif dalam perdebatan publik serta mampu membuat keputusan rasional berkaitan dengan sosial dan politik yang sedang terjadi. 
Hal diatas diperburuk dengan 'kebutaan' khalayak terhadap aturan main media dalam melaksanakan operasional keseharian. Rambu-rambu hukum yang meliputi UU Pers, UU Penyiaran, UU Perlindungan Konsumen, UU Anti Kekerasan Dalam Rumah Tangga beserta turunan Peraturan Pemerintah dan Surat Keputusan Menteri, dan Kode Etik Profesi Wartawan, Penyiaran Radio dan Televisi, dan Periklanan telah menetapkan hak-hak khalayak/konsumen media serta kewajiban pengelola dan profesi media. Disamping itu, miskinnya ketrampilan khalayak dalam 'membaca' teks-teks media, kian memperlemah posisi mereka saat berhadapan dengan tampilan media. Kebutaan mereka terhadap aspek-aspek produksi, pengemasan dan penyuguhan teks-teks media menjadikan warga tidak berdaya mengahadapi serangan beragama pesan budaya asing tersebut.Media sebagai wahana demokrasi, dengan demikian, tak ubahnya sebuah kendaraan untuk melanggengkan kepentingan bisnis media dan sarana menangguk keuntungan belaka. Idealisme demokrasi yang bertujuan untuk mencerdaskan dan mencerahkan warga negara (citizen) lenyap begitu saja ditelan hingar-bingar mesin-mesin raksasa kapitalis media. Ini seperti premis teori Marxis tentang posisi media dalam sistem kapitalis modern yang mengatakan 'Media massa adalah kelas yang mengatur".Media massa diyakini bukan hanya merupakan tempat lalu lalangnya pesan antara unsur-unsur sosial dalam suatu masyarakat, tapi juga menjadi alat penundukan dan pemaksaan konsensus oleh kelompok yang secara politik dan ekonomi dominan. Lewat pola-pola kepemilikan dan produk-produk yang disajikan, media adalah perangkat ideologis yang melanggengkan dominasi kelas pemodal terhadap publik yang diperlakukan semata-mata sebagai konsumen. Disamping itu, media juga medium untuk memciptakan opini public demi memperlancar lahirnya regulasi yang pro pasar (Agus Sudibyo:2004:1).

\section{Memahami Kinerja dan Proses Produksi Teks Pers}

Angin segar kebebasan berekspresi yang sedang berhembus dan dinikmati masyarakat dan pers nasional merupakan buah perjuangan panjang dari reformasi. Kebebasan berpendapat yang merupakan salah satu aspek Hak Asasi Manusia (HAM) ini mutlak diperlukan bagi tercapainya sebuah tatanan kehidupan bernegara yang demokratis untuk mewujudkan sebuah masyarakat yang sejahtera lahir batin dan berkeadilan sosial. Untuk menggapai citacita ini, pers sebagai agen informasi, pendidikan, hiburan dan kontrol sosial memiliki peran strategis untuk membantu 
mewujudkan hal tersebut. Melalui fungsi kontrol sosialnya, pers dapat memonitor dan mengawasi setiap perilaku penguasa, pengusaha dan masyarakat yang menyimpang dari kepentingan rakyat sehingga terjadi keseimbangan (check \& balances) dalam kehidupan bernegara. Pers, makanya, seringkali dijuluki sebagai pilar keempat demokrasi (the fourth estate of democracy). Meski demikian, posisi pers sebagai lembaga sosial (politik) dan ekonomi mengundang kerawanan terhadap 'godaan' penyimpangan untuk lebih mengutamakan kepentingan sempitnya (politik dan ekonomi) yang secara perlahan akan kian menjauhkan kinerja pers dari kepentingan rakyat.

Dengan demikian, kebebasan berpendapat yang telah dinikmati pers nasional bisa saja diselewengkan untuk memenuhi kepentingan perusahaan pers yang bersangkutan. Untuk itu, diperlukan pilar kelima demi menegakkan kehidupan demokrasi, yakni masyarakat sipil yang cerdas dan kritis dalam mengkonsumsi produk pers. Dengan kata lain, peran serta masyarakat mutlak diperlukan demi memelihara kebebasan berpendapat pers ini sehingga kinerja pers nasional benar-benar berjalan sesuai dengan amanat UU Pers dan UU Penyiaran. Mengingat strategisnnya peran serta masyarakat dalam menjaga kebebasan pers, kedua UU tersebut mendorong masyarakat untuk terlibat aktif memantau kinerja pers agar mereka terhindar dari tindakan pers yang merugikan kepentingan mereka. Hal ini tercantum dalam pasal 17 ayat 1 dan 2 UU Pers dan pasal 52 ayat 1,2, dan 3. Peran serta ini dapat diartikan kecerdasan mengkonsumsi isi media (media literacy) yang memungkinkan masyarakat untuk mampu memahami, menganalisa proses produksi teks, membangun realitas media beserta aspek sosial, politik, ekonomi etis dan legal yang menyertai proses tersebut. Dengan bekal ketrampilan ini, diharapkan warga masyarakat mampu memilah dan memilih jenis informasi yang tersuguhkan di media yang akan membantu mereka membuat keputusan yang tepat dalam melakukan sebagai warga negara.

Demi menjamin bahwa pers bekerja seperti yang dicita-citakan, wartawan diikat oleh Kode Etik Jurnalistik yang telah ditetapkan asosiasi profesi wartawan. Meski beragam asosiasi jurnalis telah lahir yang berjumlah hingga mencapai 26 organisasi. Kode Etik Jurnalistik terdiri dari : (a) Akurasi berita; (b) Obyektivitas; (c) Keberimbangan berita; (d); Impartialitas /tidak berpihak; (e) Asas praduga tidak bersalah; (f) Penghargaan terhadap harkat dan martabat manusia. Ketidakpatuhan terhadap prinsip-prinsip tersebut bisa 
berimplikasi hukum, bisa menjerumuskan wartawan ke meja hijau akibat bertentangan dengan aturan KUHP. Salah satu hal yang bisa menyeret insan pers ke meja hijau adalah: (a) Pencemaran nama baik (pasal 310 KUHP.

\section{Media Literacy}

Media Literacy bukan cuma berarti mampu menggunakan sebuah medium.Namun ia merupakan sebuah kesadaran dan kecakapan komprehensif, untuk menempatkan diri individu dan masyarakat di depan media sebagai pelaku yang aktif. Dengan kecakapan bermedia, seseorang diharapkan mampu melakukan seleksi terhadap media atau isi media yang ingin dikonsumsinya; begitu pula isi program yang ingin diproduksi (kalau dia praktisi media). Kecakapan ini menumbuhkan kesadaran tentang hak dan kewajiban seseorang, baik konsumen maupun produsen, di depan media. Termasuk pengetahuan tentang proses produksi isi media, atau konstruksi sosial industri media dengan kepentingan politik dan ideologi di belakangnya. Hal ini mengingat kenyataan bahwa media adalah kenyataan integral dari kehidupan sehari-hari hampir setiap orang. Tanpa kecakapan bermedia, setiap orang hanya akan menjadi "buruh" industri media, walau mungkin dia merasa dirinya bahagia secara semu dalam posisi "penikmat media".
Fenomena ini sudah dapat dianggap menyedihkan di Indonesia, jika dikaitkan dengan membanjirnya dan berpanjangpanjangnya tayangan sinetron domestik dan impor yang sebetulnya sama saja logika cerita dan rasa penggrapannya.. Alasan dibalik semua itu, semata karena itulah "keinginan pemirsa", padahal keinginan tersebut diprovokasi, dengan memberondongkan siaran-siaran tersebut sebagai bagian terbesar dari cuma segelintir pilihan bagi pemirsa. Yang paling menyedihkan, justru kalau kegelisahan itu sudah tidak ada lagi di hati pemirsa. Berarti keadaan ini dapat digolongkan ke dalam "hegemoni", dimana telah muncul sebuah "kesadaran palsu" ("false consciousness") di kalangan pemirsa, dan dengan itu telah menyusut atau bahkan mati, kecakapan bermedianya (Efendi Gazali et. Al : 2004: 157-158).

Terdapat dua pandangan mengenai media literacy yaitu dari Art Silverblatt dan James Potter ( 2001: ). Silverblatt menyatakan bahwa media literacy memiliki lima elemen , yaitu :

1. Kesadaran akan dampak media terhadap individu dan masyarakat

2. Sebuah pemahaman akan proses komunikasi massa 
3. Pengembangan strategi-strategi yang digunakan untuk menganalisis dan membahas pesan-pesan media

4. Sebuah kesadaran akan isi media sebagai 'teks' yang memberikan wawasan dan pengetahuan ke dalam budaya kontemporer manusia dan diri manusia sendiri

5. Peningkatan kesenangan, pemahaman dan apresiasi terhadap isi media.

Di sisi lain, Potter (Baran and Davis, 2003) memberikan pendekatan yang agak berbeda dalam menjelaskan ide-ide mendasar dari media literacy, yaitu:

1. Sebuah rangkaian kesatuan, yang bukan merupakan kondisi kategori yang terpisah

2. Media literacy perlu dikembangkan dengan melihat tingkat kedewasaan seseorang

3. Media literacy bersifat multidimensi, yaitu domain kognitif yang mengacu pada proses mental dan proses berpikir, domain emosi yaitu dimensi perasaan, domain estetis yang mengacu pada kemampuan untuk menikmati, memahami dan mengapresiasi isi media dari sudut pandang artistik, dan domain moral yang mengacu pada kemampuan untuk menangkap nilai-nilai yang mendasari sebuah pesan
4. Tujuan media literacy adalah membekali konsumen media kontrol dan kendali yang memadai untuk menafsirkan pesan.

Beberapa definisi media literacy (Stanley J.Baran: 2002: 51) dapat dipaparkan dibawah ini:

- The ability to access, analyze, evaluate, and communicate messages (National Leadership Conference on Media Literacy) ; kemampuan untuk mengakses, menganalisa, mengevaluasi dan mengkomunikasikan pesan.

- Understanding cultural, economic, political and technological constrainsts on the creation, production, and transmission of messages (Paul Messaris) : Pemahaman tentang kendala-kendala cultural, ekonomis, politis dan teknologis dalam menciptakan, memproduksi dan menyebarluaskan pesan.

- About understanding the source and technologies of communication, the codes that are used, the messages that are produced, and the selection, interpretation, and impact of those 
messages (Ruben Went) :

Pemahaman tentang sumber dan teknologi komunikasi, kode-kode simbolis yang digunakan, pesanpesan yang tercipta, serta pemilihan, penafsiran dan dampak dari pesanpesan tersebut.

- The right to acquire information and skills necessary to participate fully in public deliberation and communication. This requires facility in reading, writing, and storytelling ; critical media awareness, computer literacy: education about the role of communication in society (The Cultural Environment Movement). : Hak untuk memperoleh informasi dan ketrampilan yang diperlukan untuk berpartisipasi secara penuh dalam komunikasi dan diskusi public. Hal ini mempersyaratkan kemampuan membaca, menulis dan menceritakan; kesadaran bermedia secara kritis; melek computer; pendidikan tentang peran media terhadap masyarakat.

- Being a critical and reflective consumer of communication requires an understanding of how words, images, graphics, and sounds work together in ways that are both subtle and profound. Mass media influence the way the meanings are created and shared in contemporary society. So great is this impact that in choosing how to send a message and evaluate its effect, communicators need to be aware of the distinctive characteristics of each medium (The National Communication Association) : Menjadi konsumen media yang reflektif dan kritis mempersyaratkan adanya sebuah pemahaman tentang bagaimana katakata, gambar grafis dan suara dapat berperan untuk mempengaruhi khalayak secara mendapat dan komplek. Media massa dapat mempengaruhi bagaimana makna diciptakan dan dirasakan bersamasama oleh warga masyarakat. Begitu besar dampak hal ini sehingga komunikator hendaknya menyadari watak unik masing-masing medium.

Dari paparan di atas bisa disimpulkan bahwa media literacy bukan membentengi dan melindungi khalayak dari dampak negatif media, sebab media telah menyatu dalam kehidupan masyarakat. Hal ini adalah upaya membantu mereka untuk menjadi trampil, kritis dan cakap terhadap berbagai ragam format media sehingga mereka dapat mengendalikan dan mengarahkan tafsiran 
mereka terhadap terpaaan konten media yang dihadapi. Untuk hal ini mereka harus memiliki daya pikir kritis (critical thinking) dan kemampuan mengungkapkan diri (self expression) lewat simbol bahasa. Tanpa belal ketrampilan tersebut, seseorang tidak akan mampu berperan aktif dalam masyarakat demokratis yang mempersyaratkan adanya partisipasi penuh dalam urusan bersama yang menyangkut hajat hidup masyarakat.

\section{Konsep Literasi Media}

Pengertian media literacy menurut Center for Media Literacy (2003 : 22 ) Kanada, secara garis besar memiliki lima aspek. Pertama, pesan media adalah merupakan konstruksi, bukan refleksi atau pantulan realitas sosial. Kedua, pesan media

Tabel 1

Lima Konsep Penting Media Literacy CML

\begin{tabular}{|l|l|l|}
\hline No & Konsep Penting & Rincian \& Pertanyaan Utama \\
\hline 1 & $\begin{array}{l}\text { Pesan media adalah hasil } \\
\text { konstruksi }\end{array}$ & $\begin{array}{l}\text { Siapa pembuat teks tersebut? ; Berapa orang } \\
\text { yang terlibat dalam proses produksi pesan } \\
\text { tersebut? Jenis teks apa yang dihasilkan?; Jenis } \\
\text { teknologi apa yang digunakan? Elemen-elemen } \\
\text { apa saja yang digunakan untuk membentuk } \\
\text { keseluruhan isi teks tersebut? Apa saja yang } \\
\text { dipertahankan dan dihilangkan dari teks } \\
\text { tersebut? }\end{array}$ \\
\hline 2 & $\begin{array}{l}\text { Pesan media dikonstruksi dengan } \\
\text { menggunakan sebuah bahasa } \\
\text { kreatif dengan aturan yang khusus }\end{array}$ & $\begin{array}{l}\text { Unsur-unsur yang membentuk teks seperti } \\
\text { simbol, warna, suara, keheningan dan gerakan; } \\
\text { sudut pandang kamera yang digunakan; } \\
\text { bagaimana cerita tersebut disampaikan dengan } \\
\text { memanfaatkan simbol, metafor, apa yang } \\
\text { memiliki daya pikat emosional? ; Apa yang } \\
\text { membuatnya seperti nyata? }\end{array}$ \\
\hline
\end{tabular}

dikonstruksi menggunakan sebuah bahasa kreatif dengan aturan yang khusus. Ketiga, setiap orang menafsirkan pesan media secara berbeda. Keempat, media memiliki nilai-nilai dan pandangan-pandangan tertentu yang diselipkan dalam pesan media. Kelima, kebanyakan pesan media dikonstruksi untuk memperoleh keuntungan atau kekuasaan. Kelima hal tersebut secera rinci dapat dijelaskan pada tabel di bawah ini. 


\begin{tabular}{|l|l|l|}
\hline 3 & $\begin{array}{l}\text { Setiap orang akan memahami dan } \\
\text { mengalami pesan media yang } \\
\text { sama secara berbeda }\end{array}$ & $\begin{array}{l}\text { Bagaimana teks tersebut seusai dengan } \\
\text { pengalaman nyata khalayak; Apa yang bisa } \\
\text { dipelajari dari teks tersebut; bagaimana pula } \\
\text { teks tersebut mampu mendorong khalayak } \\
\text { untuk mempelajari diri mereka?; Bagaiman } \\
\text { caranya agar bisa mempelajari response dan } \\
\text { pengalaman orang lain dari teks tersebut? ; } \\
\text { Berapa tafsiran yang muncul dari teks tersebut? }\end{array}$ \\
\hline 4 & $\begin{array}{l}\text { Media memiliki nilai-nilai dan } \\
\text { pandangan-pandangan tertentu } \\
\text { yang diselipkan dalam pesan }\end{array}$ & $\begin{array}{l}\text { Nilai-nilai ekonomi atau politik apa yang ingin } \\
\text { disampaikan lewat pesat tersebut? Jenis } \\
\text { tindakan dan konsekwensi apa yang } \\
\text { digambarkan? Ide dan nilai apa ingin dijual } \\
\text { dalam pesan tersebut? Siapa dan apa yang } \\
\text { dihapuskan dari penggambaran pesan tersebut? }\end{array}$ \\
\hline 5 & $\begin{array}{l}\text { Kebanyakan pesan-pesan media } \\
\text { dikonstruksikan } \\
\text { memperoleh keuntungan dan } \\
\text { kekuasaan }\end{array}$ & $\begin{array}{l}\text { Siapa yang mengendalikan proses produksi dan } \\
\text { penyampaian pesan tersebut? Siapa yang } \\
\text { mengambil keuntungan dan siapa yang harus } \\
\text { membayar? Siapa yang menang; kalah dan } \\
\text { mengambil putusan akhir?; bagaimana uang, } \\
\text { seks dan kekuasaan digambarkan }\end{array}$ \\
\hline
\end{tabular}

Sumber : Center for Media Literacy (2003 : 22) Dengan makna yang sama tapi dengan ungkapan berbeda, David Buckingham (2001: 290)

Memaparkan enam konsep untuk dapat menjelaskan esensi media literacy. Konsep tersebut dapat dipaparkan dalam tabel di bawah ini.

Tabel 2

Konsep Utama Media Literacy

\begin{tabular}{|l|l|}
\hline Agen Media & $\begin{array}{l}\text { Siapa memproduksi teks : peran dalam proses produksi; lembaga } \\
\text { media; ekonomi dan ideologi; niat dan hasil }\end{array}$ \\
\hline Kategori Media & $\begin{array}{l}\text { Media Ragam Media (televisi, radio, film dll) ; bentuk } \\
\text { (dokumenter, iklan dll), genre (fiksi pengetahuan, opera sabun,dll } \\
\text { ); cara lain mengkategorikan teks; bagaimana k ategorisasi } \\
\text { berkaitan dengan tingkat pemahaman }\end{array}$ \\
\hline Teknologi Media & $\begin{array}{l}\text { Jenis media apa yang tersedia serta untuk siapa disajikan; } \\
\text { bagaimana menggunakannya ; perbedaaan yang muncul antara } \\
\text { proses produksi dengan hasil akhir yang diperoleh }\end{array}$ \\
\hline Bahasa Media & $\begin{array}{l}\text { Bagaimana media memproduksi makna, kode-kode dan konvensi } \\
\text { dan struktur naratif }\end{array}$ \\
\hline
\end{tabular}




\begin{tabular}{|l|l|}
\hline Khalayak Media & $\begin{array}{l}\text { Bagaimana mengidentifikasi, mengkonstruksikan, mencapai } \\
\text { khalayak; bagaimana audiens menemukan, memilih, } \\
\text { mengkonsumsi dan menanggapi teks }\end{array}$ \\
\hline $\begin{array}{l}\text { Representasi } \\
\text { Media }\end{array}$ & $\begin{array}{l}\text { Hubungan antara teks media dan tempat, orang, kejadian, ide, } \\
\text { stereotipe yang sesungguhnya beserta konsekwensinya }\end{array}$ \\
\hline
\end{tabular}

Sumber : David Buckingham (2001: 290

Masih dengan nada gagasan yang sama, Divina Frau-Meigs (2006: 45) mengajukan empat konsep utama berkaitan dengan bagaimana mengajarkan ketrampilan media. Menurut Divina (2006: 45) keempat konsep adalah: Pertama, produksi (apa): siapa yang memiliki media?; teknologi produksi dan distribusi yang digunakan; profesional yang membuat teks; kepemilikan industri; Keterkaitan dengan media lain, komersialisme; regulasi; Sirkulasi dan distribusi nesan: Akses dan partisipasi (suara siapa yang lebih diutamakan dan dikucilkan). Kedua, bahasa (apa) : makna ; konvensi, sandi-sandi;pilihan, genre, kombinasi beragam bahasa (suara, gambar, musik). Ketiga, representasi (apa): realisme (teks ini menggambarkan kenyataan?); menyampaikan kebenaran; presensi dan absensi (apa yang dihadrikan dan yang dihilangkan); bias dan obyektivitas: stereotipe; tafsiran; pengaruh. Keempat, Khalayak (siapa): Targetting (bagaimana media menyasar khalayak tertentu serta bagaimana memikat mereka?); Address (bagaimana media berbicara dengan mereka serta mereka asumsi apa yang dibuat produsen media tentang khalayak; Diffusion (bagaimana media mencapai khalayak); Uses (bagaimana khalayak menafsirkan media); Pleasure (kenikmatan apa yang diperoleh khalayak dari media); Social differences (bagaimana perbedaan sosial ikut mempengaruhi perilaku khalayak).

\section{Proses Memperoleh Ketrampilan Kecakapan Media}

Media literacy merupakan perluasan konseptualisasi melek huruf yang mencakup kemampuan mengakses, menganalisis, mengevaluasi dan menciptakan pesan dalam beragam bentuk pesan . Keempat ketrampilan menurut Center for Media Literacy (2003: 16) dapat dijelaskan sebagai berikut. Pertama, kemampuan mengakses (Access skills): kemampuan untuk membaca, memahami pesan serta pengetahuan tentang bagaimana menemukan dan dan memilih pesan untuk memenuhi kepentingan tertentu. Hal ini mencakup kemampuan: membaca pesan cetak dan multi media dengan tingkat pemahaman tinggi. Memahami beragam kosa kata dan simbol serta teknik-teknik komunikasi. Mengembangkan strategi 
mencari dan memanfaatkan informasi dari berbagai sumber. Memilah dan memilih informasi yang relevan untuk tujuan tertentu.

Kedua, kemampuan menganalisis (Analysis skills): memahami maksud, ide utama produsen teks serta mengembangkan strategi untuk memikat khalayak dengan menggunakan bentuk-bentuk, dan konvensi tertentu. Hal ini juga mencakup ketrampilan mengungkap konteks-konteks sosial, politik, ekonomi dan historis dari pesan yang disebarluaskan. Hal ini seperti bagaimana cara menggunakan pengalaman dan pengetahuan terdahulu untuk memprediksi hasil; Menafsirkan pesan dengan menggunakan konsep-konsep seperti maksud, gagasan utama, bentuk, karakter tokoh, plot, tema, konteks; bagaimana mengungkapkan gagasan dengan menggunakan strategi strategis seperti memperbandingkan/memperlawankan, sebab/akibat, membuat list daftar dan urutan ; Menggunakan pengetahuan tentang konteks sosial, politik, ekonomi, dan historis pada pesan yang digunakan dalam menciptakan dan menafsirkan pesan tersebut. Ketiga, kemampuan mengevaluasi (Evaluation skills); mampu menilai kualitas, keaslian, akurasi dan relevansi pesan. Hal ini meliputi ketrampilan menentukan nilai dan kelayakan pesan dalam kaitannnya dengan pesan lain dari dari sumber yang berbeda; mengaitkan satu teks dengan teks lain sejenis dari beragam sumber. Kemampuan ini selanjutnya dapat dijabarkan :Mampu mengapresiasi dan menikmati saat menafsirkan pesan dalam beragam bentuk dan genre aliran. Memberi tanggapan baik secara tulisan maupun lisan terhadap pesanpesan yang beragam kompleksitas dan isinya. Mengevaluasi kualitas sebuah pesan berdasarkan isi dan bentuknya. Menilai sebuah pesan berdasarkan prinsip-prinsip etika, budaya, agama dan demokrasi. Keempat, kemampuan mencipta (Creation skills): mampu menuliskan gagasan dengan menggunakan kosa kata, suara dan gambar secara efektif untuk berbagai tujuan; memanfaatkan berbagai teknologi komunikasi untuk menciptakan, menyunting dan menyebarluaskan pesan yang persuasif, informatif dan menghibur. Ini dapat dijabarkan dengan kemampuan : Menggunakan proses brainstorming (pencarian ide), perencanaan, penyusunan dan penyuntingan. Ini berarti kemampuan menggunakan bahasa tulisan dan lisan secara efektif dengan menguasai aturan pemakaian bahasa tersebut. Menciptakan dan memilih gambar secara efektif untuk mencapai berbagai tujuan. Menggunakan teknologi komunikasi dalam menkonstruksikan pesan.

Media Literacy dan Kewargaan Aktif (Active Citizenship) 
Media yang berisikan realitas yang telah dikonstruksi dan disisipi kepentingan ekonomi politik para kapitalis media ibarat peluru ajaib yang memborbardir khalayak yang tidak berdaya menghadapi beragam pesan. Kebebasan berekpresi media massa yang sejatinya diarahkan untuk mendorong proses demokratisasi dan mensejahterakan bangsa pada akhirnya akan berubah menjadi sarana untuk mengeruk keuntungan politik para kapitalis media. Situasi ini diperperah dengan tidak berdayanya lembaga negara untuk melindungi kepentingan rakyat. Ketrampilan rakyat untuk mengevalusi isi media serta menciptakan media atau biasa disebut media kecakapan bermedia) menjadi hal yang mendesak bagi warga masyarakat untuk membentengi diri mereka dari gempuran kepentingan sempit media meski dengan kedok 'memenuhi kepentingan masyarakat'.

Singkat kata, kebebasan bereskpresi pers nasional saat ini memang telah sedikit banyak telah mampu mendorong proses demokratisasi. Beberapa pemberitaan pers yang kritis tentang penyelewengan yang dilakukan penyelenggaran negara telah mampu -nembentuk opini publik kuat yang lantas dibarengi dengan perubahan dalam tatanan kehidupan berbangsa. Rakyatpun tercerahkan oleh pemberitaan seperti ini. Meski demikian, kebebasan berpendapat pers saat ini tidak serta merta mampu memperlancar proses demokratisasi kalau tidak diikuti dengan partisipasi aktif warga dalam mempengaruhi proses pembuatan keputusan publik. Media literacy yang berintikan daya pikir kritis diharapkan mampu mendorong terbangunnya warga yang aktif. Lewat media literacy yang berintikan ketrampilan daya pikir kritis dan kecakapan mengungkapkan diri dapat mendorong terbangunnya kewargaan aktif (active citizenship). Hal ini karena tujuan utama media literacy menurut Justin Lewis dan Sut Jhally (1998: 1) adalah untuk membantu warga masyarakat menjadi warga yang cerdas bukan konsumen yang cerdas. Lebih lanjut Lewis dan Jhallay menyatakan dengan mengutip Len Masterman (2001) bahwa: "Keberhasilan proses demokratisasi akan ditentukan oleh kemampuan mayoritas warga masyarakat untuk mengambil kendali, dan menjadi agen perubahan yang efektif, membuat keputusan rasional (yang biasanya berdasarkan bukti dari media) serta mampu berkomunikasi secara aktif lewat berpartisipasi aktif dengan media massa".

Disinilah letak nilai pentingnya media literacy dalam membangun kewargaan aktif. Hal ini menurut Renee Hobbs dalam situs medialit.org karena adanya keterkaitan yang erat antara media komunikasi, pendidikan media literacy dan demokrasi. 
Demokrasi tidak akan bermakna tanpa adanya beragam aspirasi. Demikian juga akan sulit mengembangkan kewargaan aktif tanpa kehadiran media massa. Hobbs memaparkan ada tiga cara bagaimana media literacy bisa mendorong terbangunnya kewargaan aktif: Pertama, media literacy dapat membantu warga memperoleh ketrampilan mengakses, menganalisis informasi serta berkomunikasi dan mengembangkan sebuah apresiasi tentang pentingnya memahami dunia sekitar . Kedua, media literacy dapat mendukung dan mengembangkan sebuah lingkungan pembelajaran yang memungkinkan masyarakat untuk menerapkan kecakapan memimpin, mengungkapkan diri secara bebas dan bertanggunjawab, mengembangkan consensus dan resolusi resolusi konflik. Ketiga, kecakapan media dapat mendorong warga untuk lebih tertarik meningkatkan akses mereka terhadap berbagai sumber informasi.

Dengan demikian, media literacy merupakan hal mendesak untuk diterapakan demi memacu dan memperlancar proses demokratisasi. Nilai penting media literacy menurut Tessa Jolls (2008: 12) adalah sebagai berikut : Pertama, Pengaruh media sangat penting dalam proses demokratisasi sebab media literacy mampu memberikan kecakapan berpikir kritis (critical thinking) dan ketrampilan mengungkapkan diri (self expression); dua kecakapan amat diperlukan untuk membentuk warga yang aktif. Kedua, Meningkatnya derajat konsumsi media masyarakat serta menyatupadunya media dengan kehidupan masyarakat. Pesan media yang dimediasi lewat beraneka lambang telah memborbardir masyarakat. Kondisi seperti bertolakang belakang dengan kaeadaan pada generasi sebelumnya. Media literacy mengajarkan ketrampilan agar kita dapat mengarungi 'lautan gambar dan pesan' dengan selamat demi keberlangsungan hidup. Ketiga, pengaruh kuat media terhadap perubahan perilaku khalayak; pengetahuan, sikap dan tindakan masyarakat. Media telah mempengaruhi secara signifikan terhadap bagaimana masyarakat memahami, menafsirkan dan bertindak terhadap lingkungan sekililing. Dengan memahani dampak media tersebut, pendidikan media dapat membantu masyarakat mengurangi derajat ketergantungan terhadap media. Keempat, kian meningkatnya nilai penting komunikasi visual dan informasi. Dalam kehidupan yang didominasi bahasan multimedia, kemampuan 'membaca' bahasa komunikaasi visual merupakan hal yang melengkapi kecakapan berbasis komunikasi cetak. Kelima, nilai penting informasi bagi masyarakat dan perlunya pembelajaran seumur hidup bagi masyarakat. Kemampuan mengelola dan menyebarluaskan informasi 
merupakan ciri utama masyarakat informasi. Tapi dengan perkembangan pesat industry media global akan mempengaruhi cara pandang dan sikap masyarakat yang telah mapan. Pendidikan media, makanya akan membantu masyarakat memahami menelisik asal muasal informasi, kepentingan siapa yang dilayani serta bagaimana menemukan alternatif pandangan yang lain.

Hasil akhir dari pendidikan media adalah masyarakat yang berdaya yang mampu bersahabat dengan pesan media ; yang memiliki daya berpikir kritis dan mengungkapkan pesan secara kreatif sehingga memampukannya untuk membuat keputusan rasional serta berpartisipasi dalam kehidupan sosial politiknya. Ini karena pendidikan media disandarkan pada proses mempertanyakan (process of inquiry). Hal ini dapat dilihat dari terjadi spiral pemberdayaan (spiral of empowerment) dalam proses pendidikan media (Tessa Jolls . 2008: 65). Konsep ini papar Tessa Jolls (2008; 65) didasarkan pada pemikiran pendidikan popular Brazil Paulo Freire yang memaparkan bagaimana mengklasifikasikan konsep atau topik yang kompleks menjadi empat langkah tahapan pembelajaran. Empat tahapan yang terdiri dari kesadaran, analisis, refleksi dan aksi ini, menurut Tessa Jolls akan merangsang pertumbuhan beberapa bagian otak dan meningkatkan kemampuan masyarakat untuk dapat mengembangkan pengetahuan baru dari pengetahuan yang telah dimiliki. Setelah mempertanyakan secara kritis konten pesan media, seseorang akan memperoleh kesadaran tentang makna pesan tersebut. Tahapan analisis akan memberikan seseorang peluang untuk menggambarkan "bagaimana" sebuah isu yang kompleks dapat disajikan secara estetis dalam pesan media. Juga, membayangkan secara visual "apa" yang terjadi kalau pesan yang tersaji disusun dengan berpikir bertentang dengan alur piker sang pembuat pesan. Yang terpenting di sini adalah bahwa kemampuan menggambarkan dampak representasi pesan produk serta memahami bagaimana kontruksi pesan ini juga akan berpengaruh terhadap makna pesan. Tahapan refleksi adalah merenungkan secara mendalam "lantas apa" serta "apa yang harus dilakukan atau dipikirkan'. Pada tahapan akhir yakni aksi, seseorang belajar dengan bekerja dan melaksanakan sesuatu baik secara pribadi atau kolektif. Di sini tersedia peluang untuk menyusun rencana tindakan secara kreatif. Tindakan di sini tidak selalu berarti melakukan tindakan merupakan secara nyata. Memutuskan untuk tidak bertindak juga berarti aksi (Tessa Jolls . 2008: 65-67)

Pengertian Kewargaan Aktif (Active Citizenship) 
Konsep kewargaan, menurut Chris McInerney (2004; 6) mengandung dua pengertian. Pertama, merujuk kepada status hukum warga dengan beragam hak-hak dan kewajiban warga sipil universal seperti hak politik, sosial, ekonomi dan budaya yang diberikan negara. Kedua, menekankan pada keterlibatan aktif warga dalam urusan-urusan publik serta proses pembuatan keputusan publik yang memiliki dampak langsung terhadap kehidupan mereka. Kewargaan dengan demikian berarti sebuah status hukum warga dengan beraneka hak dan kewajiban. Juga, kewargaan merujuk kepada tindakan aktif warga yang ikut terlibat dalam proses pembuatan keputusan dan menjadi pelaku dalam mengelola permasalahan mereka sendiri dan urusan nasyarakat yang lebih luas.

Kewargaan aktif papar Chris McInerney (2004;7) berarti partisipasi warga dalam mempengaruhi proses pengambilan kebijakan-kebijakan yang empengaruhi kehidupan mereka dan menuntut pertanggungjawaban para penyelenggara layanan publik. Kewenangan untuk mendefinisikan status hukum dan tindakan nyata warga ditentukan sendir oleh warga dan lembaga-lembaga, para pelaku terutama negara. Untuk hal ini perlu kesadaran dan kerjasama baik oleh warga maupun negara untuk mewujudkan kewargaan yang aktif ini. Hal ini berarti mempersyaratkan adanya saling kerjasama antara aspek penawaran dari pihak negara yakni kemampuan negara untuk menggiatkan tata pamong yang demokratis serta menanggapi tuntutan warga dan aspek tuntutan dari pihak warga; yakni kemampuan warga untuk menyuarakan dan menuntut lembaga pemerintah untuk menyerap kepentingan mereka. Kewargaan akan muncul ketika warga memiliki kesadaran atau identitas diri sebagai warga dengan hakhak yang melekat pada mereka serta mampu mewujudkan hak-hak tersebut. Ketika perasaan ini tersebar dan menancap kuat dalam benak mereka antara satu dengan yang lain, maka identitas kelompok warga akan muncul. Dari sinilah terbangun dasar dan landasan tindakan kolektif warga yang akan melahirkan klaim-klaim kelompok.

Untuk mengukur sebarapa aktif kewargaan sebuah masyarakat menurut Pedersen (2006: 11) dapat dinilai dari indikator sebagai berikut: (a) Tindakan kolektif oleh masyarakat: mereka dapat berkumpul bersama dalam kelompok formal atau informal dengan kepentingan yang sama untuk mencapai tujuan yang sama pula. Mereka lantas mampu membuat komitmen dengan pejabat pemerintah: orang memperbincangkan kebijakan dan rencana pembangunan dengan para pejabat 
pemerintah baik di pusat maupun di daerah. dan memiliki ketertarikan terhadap Mereka juga berani menuntut lembaga kehidupan publik dan permasalahan pemerintahan; orang melakukan bersama. Keempat, Percaya diri dan Harapan perbincangan dengan pejabat pemerintahan (self confidence and Expectation): ekspektasi untuk menyuarakan kepentingan mereka dan percaya diri akan hadir ketika serta menuntut pemerintah memenuhi hak- masyarakat memiliki harapan bahwa mereka hak mereka. Mereka juga berani menuntut bisa mempengaruhi isu-isu yang sedang pertanggungjawaban lembaga pemerintahan: diperbincangkan di masyarakat dan mampu masyarakat meminta akuntabilitas menghargai perbedaan pendapat dengan penyelenggara pemerintahan atas masyarakat lain. Kelima, Kemampuan dan pelaksanaan kebijakan publik; pelayanan ketrampilan (ability and skills) : masyarakat publik yang diberikan.

Indikator tersebut kemudian dirinci kembali oleh Pedersen (2006: 12) menjadi beberapa elemen yang saling terkait satu dengan yang lain, yang biasanya berkaitan dengan nilai-nilai, persepsi, ketrampilan dan perilaku serta konteks sosial politik dan budaya. Elemen ini dapat dijabarkan sebagai berikut. Pertama, Nilai-nilai demokratis (democratic values): toleransi, keadilan, solidaritas, kesetaraan dan perdamaian. Kedua, Identitas dan kesadaran (identity and awareness): identitas diri dan kesadaran sebagai warga hanya akan muncul kalau masyarakat memandang diri mereka sebagai warga dan pelaku yang memiliki hak-hak dan mampu bertindak secara sadar untuk mewujudkan hak-hak tersebut. Ketiga, Pemahaman dan kepentingan (understanding and interest): mampu berpikir kritis dan memahami politik dan dinamika kekuasaan mampu membentuk opini politik dan ketrampilan untuk mengkomunikasikan dan melakukan negosiasi dengan warga lain dan pejabat pemerintah. Keenam, Tindakan aktif (active behaviour); masyarakat secara aktif berusaha untuk berpartisipasi dalam kehidupan public untuk mempengaruhi proses pembuatan keputusan public. Termasuk disini adalah partisipasi dalam pertemuan dan debat publik, menyuarakan kebutuhan dan kepentingan kepada pejabat publik serta mempedulikan kehidupan sosial. Ketujuh, Suara dan pengaruh (voice and influence); berani menyatakan pendapat dan mampu mempengaruhi keputusan publik. Hal ini berarti kemampuan warga untuk berani menyuarakan kepentingan mereka dan daya tanggap negara dan lembaga lain untuk mendengarkan aspirasi masyarakat serta menyesuaikan kebijakan dengan aspirasi masyarakat. 
Paparan di atas menunjukkan bahwa ketika masyarakat memandang diri mereka sebagai pelaku dalam pemerintahan iaripada sebagai penerima pasif layanan publik, maka mereka akan lebih mampu untuk menegaskan kewargaan mereka lewat partisipasi mereka dalam mempengaruhi keputusan public yang berdampak langsung terhadap kehidupan mereka serta menuntut akuntabilitas pemerintah. Agar kewargaan ini dapat terwujud, maka negara dan lembaga lain dalam masyarakat hendaknya mengakui dan memfasilitasi diterapkannya kewargaan ini sebagai sebuah hak dan proses. Hal ini mempersayartkan adanya sebuah struktur yang demokratis dalam masyarakat dan kelembagaan negara yang yang demokratis dan transparan. Kewargaan yang aktif akan berkembang ketika negara akomodatif terhadap kepentingan masyarakat serta mau untuk melakukan perubahan dalam struktur budaya dan tindakannya.

Namun, kewargaan Aktif tidak akan terwujud menurut Chris McInerney (2004;6) tanpa dibarengi dengan pendidikan kewargaan (civic education). Pendidikan kewargaan adalah proses belajar berpartisipasi efektif dalam proses pembangunan dan demokrasi balk pada level nasional maupun lokal. Hal ini merupakan cara penting untuk membangun kapasitas masyarakat dengan memberdayakan warga masyarakat untuk terbangunya kewargaan yang efektif. Ini merupakan dimensi penting dalam rangka memperkuat kemampuan warga untuk mengelola permasalahan mereka sendiri dan untuk melengkapi proses pengembangan kapasitas individu dan lembaga-lembaga. Ini dari proses pendidikan kewargaan adalah prinsip-prinsip dan nilainilai keterbukaan, partisipasi, kepekaan, akuntabilitas dan kesetaraan. Hal ini biasanya terkait dengan tiga elemen. kecenderungan kewargaan (civic disposition), pengetahuan kewargaan (civic knowledges) dan ketrampilan kewargaan civic (civic skills). Pertama, kecenderungan Kewargaan (civic dispositions) mencakup : Kemampuan mengembangkan rasa percaya diri untuk bisa terlibat dalam kehidupan masyarakat; Partisipasi dalam kehidupan bermasyarakat; Memainkan peran, hak dan tanggungjawab berkaitan dengan kehidupan kewarrgaan dalam sistem demokratis; Bersikap terbuka, toleran dan bertanggungjawab dalam melaksanakan hak dan kewajiban. Kedua, pengetahuan kewargaan (Civic knowledge) berarti warga memahami konteks politik dan kewargaan mereka; Mengetahui hak-hak social, ekonomi, politik dan sipil mereka; Memahami peran, hak dan tanggungjawab sebagai warga. Ketiga, Ketrampilan Kewargaan (Civic skills) berarti warga: memperoleh ketrampilan untuk menjelaskan, 
menganalisis, berinteraksi, serta mengevaluai serta mempertahankan sebuah sikap dan memonitor proses dan hasil; Memanfaatkan pengetahuan untuk berpartisipasi berdasarkan informasi dalam proses politik dan kewargaan.

Dengan alur pikir yang sama, kewargaan aktif, menurut Ruud Veldhuis (2005: 19) mempersyaratkan adanya empat hal; Pertama, pengetahuan tentang politik, perundangan, sejarah perjalanan bangsa warga bersangkutan. Kedua, sikap demokratis, toleran, rasa memiliki komunitas. Ketiga, ketrampilan intelektual untuk mampu berperan aktif dalam diskusi publik, menyelesaikan konflik dengan cara damai dan mampu menafsirkan media secara efektif. Keempat, ketrampilan berpartisipasi dengan menggunakan informasi secara efektif, ketika terlibat dalam organiasasi sosial.

\section{Kewargaan Aktif (active citizenship)}

Konsep kewargaan mengandung dua pengertian. Yang pertama merujuk kepada status hukum warga dengan beragam hakhak dan kewajiban warga sipil universal seperti hak politik, sosial, ekonomi dan budaya yang diberikan negara. Yang kedua berasal dari kajian pembangunan menekankan pada keterlibatan aktif warga dalam urusan-urusan publik serta proses pembuatan keputusan publik yang memiliki dampak langsung terhadap kehidupan mereka. Kewargaan dengan demikian berarti sebuah status hukum warga dengan beraneka hak dan kewajiban. Juga, kewargaan merujuk kepada tindakan aktif warga yang ikut terlibat dalam proses pembuatan keputusan publik dan menjadi pelaku dalam mengelola permasalahan mereka sendiri dan urusan masyarakat yang lebih luas.

Kewargaan aktif berarti partisipasi warga dalam membuat kebijakan-kebijakan yang mempengaruhi kehidupan mereka dan menuntut pertanggungjawaban para penyelenggara layanan publik. Kewenangan untuk mendefinisikan status hukum dan tindakan nyata warga ditentukan oleh warga sendiri dan lembaga-lembaga, para pelaku terutama negara. Untuk itu hal ini perlu kesadaran dan kerjasama baik oleh warga maupun negara untuk mewujudkan kewargaan yang aktif ini. Hal ini berarti mempersyaratkan adanya saling kerjasama antara aspek penawaran dari pihak negara yakni kemampuan negara untuk menggiatkan tata pamong yang demokratis serta menanggapi tuntutan wargam dan aspek tuntutan dari pihak warga ; yakni kemampuan warga menyuarakan dan menuntut lembaga pemerintah untuk menyerap kepentingan mereka. Kewargaan akan muncul ketika warga memiliki 
kesadaran atau identitas diri sebagai warga dengan hak-hak yang melekat pada mereka serta mampu mewujudkan hak-hak tersebut. Ketika perasaan ini tersebar dan menancap kuat dalam benak mereka antara satu dengan yang lain, maka identitas kelompok warga akan muncul. Dari sinilah dasar tindakan kolektif warga yang akan melahirkan klaimklaim kelompok.

Untuk mengukur sebarapa aktif kewargaan sebuah masyarakat menurut Pedersen (2006: 11) dapat dinilai dari indikator sebagai berikut :

- Tindakan kolektif oleh masyarakat : orang berkumpul bersama dalam kelompok formal atau informal dengan kepentingan yang sama untuk mencapai tujuan yang sama pula.

- Masyarakat membuat komitmen dengan pejabat pemerintah : orang memperbincangkan kebijakan dan rencana pembangunan dengan para pejabat pemerintah baik di pusat maupun di daerah.

- Masyarakat berani menuntut lembaga pemerintahan ; orang melakukan perbincangan dengan pejabat pemerintahan untuk menyuarakan kepentingan mereka serta menuntut pemerintah memenuhi hak-hak mereka.
- Masyarakat berani menuntut pertanggungjawaban lembaga pemerintahan : masyarakat meminta akuntabilitas penyelenggara pemerintahan atas pelaksanaan kebijakan public; pelayanan publik yang diberikan.

Indikator tersebut kemudian dirinci kembali oleh Pedersen (2006: 12) menjadi beberapa elemen yang saling terkait satu dengan yang lain, yang biasanya berkaitan dengan nilai-nilai, persepsi, ketrampilan dan perilaku serta konteks social politik dan budaya. Elemen ini terdiri dari :

1. Nilai-nilai demokratis (democratic values) : toleransi, keadilan, solidaritas, kesetaraan dan perdamaian.

2. Identitas dan kesadaran (identity and awareness): identitas diri dan kesadaran sebagai warga hanya akan muncul kalau masyarakat memandang diri mereka sebagai warga dan pelaku yang memiliki hakhak dan mampu beritndak secara sadar untuk mewujudkan hak-hak tersebut.

3. Pemahaman dan kepentingan (understanding and interest) : mampu berpikir kritis dan memahami politik dan dinamika kekuasaan dan 
memiliki ketertarikan terhadap kehidupan publik dan permasalahan bersama.

4. Percaya diri dan Harapan (self confidence and Expectation): ekspektasi dan percaya diri akan hadir ketika masyarakat memiliki harapan bahwa mereka bisa mempengaruhi isu-isu yang sedang diperbincangkan di masyarakat dan mampu berbeda pendapat dengan masyarakat lain.

5. Kemampuan dan ketrampilan (ability and skills) : masyarakat mampu membentuk opini politik dan ketrampilan untuk mengkomunikasikan dan melakukan negosiasi dengan warga lain dan pejabat pemerintah.

6. Tindakan aktif (active behaviour); masyarakat secara aktif berusaha untuk berpartisipasi dalam kehidupan public untuk mempengaruhi proses pembuatan keputusan public. Termasuk disini adalah partisipasi dalam pertemuan dan debat publik, menyuarakan kebutuhan dan kepentingan kepada pejabat publik serta mempedulikan kehidupan sosial.

7. Suara dan pengaruh (voice and influence) ; berani menyatakan pendapat dan mampu mempengaruhi keputusan publik. Hal ini berarti kemampuan warga untuk berani menyuarakan kepentingan mereka dan daya tanggap negara dan lembaga lain untuk mendengarkan aspirasi masyarakat serta menyesuaikan kebijakan dengan aspirasi masyarakat.

Ketika masyarakat memandang diri mereka sebagai pelaku dalam pemerintahan daripada sebagai penerima pasif layanan publik, maka mereka akan lebih mampu untuk menegaskan kewargaan mereka lewat partisipasi mereka dalam mempengaruhi keputusan public yang berdampak langsung terhadap kehidupan mereka serta menuntut akuntabilitas pemerintah. Agar kewargaan ini dapat terwujud, maka negara dan lembaga lain dalam masyarakat hendaknya mengakui dan memfasilitasi diterapkannya kewargaan ini sebagai sebuah hak dan proses. Hal ini mempersayartkan adanya sebuah struktur yang demokratis dalam masyarakat dan kelembagaan negara yang yang demokratis dan transparan. Kewargaan yang aktif akan berkembang ketika negara akomodatif terhadap kepentingan masyarakat serta mau untuk melakukan perubahan dalam struktur budaya dan tindakannya.

Namun, kewargaan Aktif tidak akan terwujud menurut Chris McInerney (2004;6) 
tanpa dibarengi dengan pendidikan kewargaan (civic education). Pendidikan kewargaan adalah proses belajar berpartisipasi efektif dalam proses pembangunan dan demokrasi baik pada level nasional maupun lokal. Hal ini merupakan cara penting untuk membangun kapasitas masyarakat dengan memberdayakan warga masyarakat untuk terbangunya kewargaan yang efektif. Ini merupakan dimensi penting dalam rangka memperkuat kemampuan warga untuk mengelola permasalahan mereka sendiri dan untuk melengkapi proses pengembangan kapasitas individu dan lembaga-lembaga. Ini dari proses pendidikan kewargaan adalah prinsip-prinsip dan nilainilai keterbukaan, partisipasi, kepekaan, akuntabilitas dan kesetaraan. Hal ini biasanya terkait dengan tiga elemen ; kecenderungan kewargaan (civic disposition), pengetahuan kewarrgaan (civic knowledge) dan ketrampilan kewargaan civic (civic skills) :

1. Kecenderungan Kewargaan (civic dispositions) mencakup :

a. Mampu mengembangkan rasa percaya diri untuk bisa terlibat dalam kehidupan bermasyarakat.

b. Partisipasi dalam kehidupan bermasyarakat.

c. Memainkan peran, hak dan tanggungjawab berkaitan dengan kehidupan kewargaan dalam sistem demokratis.

d. Bersikap terbuka, toleran dan bertanggungjawab dalam melaksanakan hak dan kewajiban

2. Pengetahuan kewargaan (Civic knowledge) berarti warga :

a. Memahami konteks politik dan kewargaan mereka.

b. Mengetahui hak-hak social, ekonomi, politik dan sipil mereka.

c. Memahami peran, hak dan tanggungjawab sebagai warga

3. Ketrampilan Kewargaan (Civic skills) berarti warga :

a. memperoleh ketrampilan untuk menjelaskan, menganalisis, berinteraksi, serta mengevaluasi serta mempertahankan sebuah sikap dan memonitor proses dan hasil.

b. Memanfaatkan pengetahuan untuk berpartisipasi berdasarkan informasi dalam poses politik dan kewargaan.

\section{Metode penelitian.}

Penelitian ini menggunakan pendekatan deskriptif kuantitatif dengan metode survei. Lewat sampel purposif siswa kelas XII SMA Widya Gama dan SMKN Grafika diperoleh responden sejumlah 60 
orang. Adapun varibel penelitian terdiri dari media literasi sebagai variabel bebas (x) sedangkan kewargaan aktif sebagai variabel terikat (y). Untuk mengetahui adanya pengaruh variabel $\mathrm{x}$ terhadap varibel $\mathrm{y}$, maka rumus komputasi regresi linear diterapkan. Agar kedua variabel dapat diukur, maka keduanya lantas didefinisikan secara operasional sebagai berikut :

Variabel terikat (x) Media literasi adalah kemampuan untuk mengakses, menganalisa, mengevaluasi dan mengkomunikasikan pesan. Keempat ragam kemampuan ini dapat didefinisikan secara operasional sebagai berikut :

1. Kemampuan mengakses (Access skills): kemampuan untuk membaca, memahami pesan serta pengetahuan tentang bagaimana menemukan dan dan memilih pesan untuk memenuhi kepentingan tertentu. Hal ini mencakup kemampuan:

a. membaca pesan cetak dan multi media dengan tingkat pemahaman tinggi.

b. Memahami beragam kosa kata dan simbol serta teknik-teknik komunikasi.

c. Ini juga mencakup ketrampilan mengembangkan strategi mencari dan memanfaatkan informasi dari berbagai sumber serta d. memilah dan memilih informasi yang relevan untuk tujuan tertentu.

2. Kemampuan menganalisis (Analysis skills): memahami maksud, ide utama produsen teks serta mengembangkan strategi untuk memikat khalayak dengan menggunakan bentuk-bentuk, dan konvensi tertentu. Hal ini juga mencakup

a. ketrampilan mengungkap konteks-konteks sosial, politik, ekonomi dan historis dari pesan yang disebarluaskan. Hal ini seperti bagaimana cara menggunakan pengalaman dan pengetahuan terdahulu untuk memprediksi hasil;

b. Menafsirkan pesan dengan menggunakan konsep-konsep seperti maksud, gagasan utama, bentuk, karakter tokoh, plot, tema, konteks; bagaimana mengungkapkan gagasan dengan menggunakan strategi strategis seperti

memperbandingkan/memperlawa nkan, sebab/akibat, membuat list daftar dan urutan ;

c. Menggunakan pengetahuan tentang konteks sosial, politik, ekonomi, dan historis pada pesan 
yang digunakan dalam menciptakan dan menafsirkan pesan tersebut.

3. Kemampuan mengevaluasi

(Evaluation skills); mampu menilai kualitas, keaslian, akurasi dan relevansi pesan. Hal ini meliputi ketrampilan ;

a. menentukan nilai dan kelayakan pesan dalam kaitannnya dengan pesan lain dari dari sumber yang berbeda;

b. mengaitkan satu teks dengan teks lain sejenis dari beragam sumber. Kemampuan ini selanjutnya dapat dijabarkan :

c. Mampu mengapresiasi dan menikmati saat menafsirkan pesan dalam beragam bentuk dan genre aliran.

d. Memberi tanggapan baik secara tulisan maupun lisan terhadap pesan-pesan yang beragam kompleksitas dan isinya. Mengevaluasi kualitas sebuah pesan berdasarkan isi dan bentuknya. Menilai sebuah pesan berdasarkan prinsip-prinsip etika, budaya, agama dan demokrasi.

4. Kemampuan mencipta (Creation skills): mampu menuliskan gagasan dengan menggunakan kosa kata, suara dan gambar secara efektif untuk berbagai tujuan; memanfaatkan berbagai teknologi komunikasi untuk menciptakan, menyunting dan menyebarluaskan pesan yang persuasif, informatif dan menghibur. Ini dapat dijabarkan dengan kemampuan :

a. Menggunakan

proses brainstorming (pencarian ide), perencanaan, penyusunan dan penyuntingan.

b. kemampuan menggunakan bahasa tulisan dan lisan secara efektif dengan menguasai aturan pemakaian bahasa tersebut.

c. Menciptakan dan memilih gambar secara efektif untuk mencapai berbagai tujuan.

d. Menggunakan teknologi komunikasi dalam menkonstruksikan pesan.

Sedangkan variabel terikat (y) kewargaan aktif (active citizenship) adalah Kewargaan aktif papar Chris McInerney $(2004 ; 7)$ berarti partisipasi warga dalam mempengaruhi proses pengambilan kebijakan-kebijakan yang empengaruhi kehidupan mereka dan menuntut pertanggungjawaban para penyelenggara layanan publik. Indikator tersebut kemudian dirinci kembali oleh Pedersen (2006: 12) 
menjadi beberapa elemen yang saling terkait satu dengan yang lain, yang biasanya berkaitan dengan nilai-nilai, persepsi, ketrampilan dan perilaku serta konteks social politik dan budaya. Elemen ini terdiri dari :

a. Nilai-nilai demokratis (democratic values) : toleransi, keadilan, solidaritas, kesetaraan dan perdamaian.

b. Identitas dan kesadaran (identity and awareness): identitas diri dan kesadaran sebagai warga hanya akan muncul kalau masyarakat memandang diri mereka sebagai warga dan pelaku yang memiliki hakhak dan mampu beritndak secara sadar untuk mewujudkan hak-hak tersebut.

c. Pemahaman dan kepentingan (understanding and interest) : mampu berpikir kritis dan memahami politik dan dinamika kekuasaan dan memiliki ketertarikan terhadap kehidupan publik dan permasalahan bersama.

d. Percaya diri dan Harapan (self confidence and Expectation): ekspektasi dan percaya diri akan hadir ketika masyarakat memiliki harapan bahwa mereka bisa mempengaruhi isu-isu yang sedang diperbincangkan di masyarakat dan mampu berbeda pendapat dengan masyarakat lain.

e. Kemampuan dan ketrampilan (ability and skills) : masyarakat mampu membentuk opini politik dan ketrampilan untuk mengkomunikasikan dan melakukan negosiasi dengan warga lain dan pejabat pemerintah.

f. Tindakan aktif (active behaviour); masyarakat secara aktif berusaha untuk berpartisipasi dalam kehidupan public untuk mempengaruhi proses pembuatan keputusan public. Termasuk disini adalah partisipasi dalam pertemuan dan debat publik, menyuarakan kebutuhan dan kepentingan kepada pejabat publik serta mempedulikan kehidupan sosial.

g. Suara dan pengaruh (voice and influence) ; berani menyatakan pendapat dan mampu mempengaruhi keputusan publik. Hal ini berarti kemampuan warga untuk berani menyuarakan kepentingan mereka dan daya tanggap negara dan lembaga lain untuk mendengarkan aspirasi masyarakat serta menyesuaikan kebijakan dengan aspirasi masyarakat. 
Temuan Penelitian dan Pembahasan

Pada variabel media literasi, menunjukkan skor yang tinggi pada hampir semua indikator. Ini dapat dilihat pada kemampuan mengakses, menganalisis, mengevaluasi dan mencipta media. Sedangkan pada variabel terikat kewargaan aktif menggambarkan skor yang beragam pada beberapa indikator. Nilai-nilai demokrasi dan identitas \& kesadaran, percaya diri ditemukan skor tinggi. Tapi pada indikator pemahaman dan kepentingan serta tindakan aktif dan ketrampilan ditemukan skor rendah. Maka setelah dilakukan komputasi data dengan SPSS ditemukan data sebagai berikut :

Descriptive Stati stics

\begin{tabular}{|l|l|r|r|}
\hline & Mean & Std. Dev iation & $\mathrm{N}$ \\
\hline y (Kewargaan Aktif) & 41.1333 & 4.82742 & 60 \\
x (Kecerdasan Media) & 49.6667 & 3.74468 & 60 \\
\hline
\end{tabular}

\section{Correlations}

\begin{tabular}{|ll|r|r|}
\hline & & $y$ (Kewargaan \\
Aktif) & $\begin{array}{c}\text { x (Kecerdasan } \\
\text { Media) }\end{array}$ \\
\hline Pearson Correlation & y (Kewargaan Aktif) & 1.000 & .437 \\
& x (Kecerdasan Media) & .437 & 1.000 \\
\hline Sig. (1-tailed) & y (Kewargaan Aktif) &. & .000 \\
& x (Kecerdasan Media) & .000 & .60 \\
\hline N & y (Kewargaan Aktif) & 60 & 60 \\
\hline
\end{tabular}

Model Summary

\begin{tabular}{|l|r|r|r|r|}
\hline Model & \multicolumn{1}{|c|}{$\mathrm{R}$} & R Square & $\begin{array}{c}\text { Adjusted } \\
\text { R Square }\end{array}$ & $\begin{array}{c}\text { Std. Error of } \\
\text { the Estimate }\end{array}$ \\
\hline 1 & $.437^{\mathrm{a}}$ & .191 & .177 & 4.38027 \\
\hline
\end{tabular}

a. Predictors: (Constant), x (Kecerdasan Media)

b. Dependent Variable: y (Kewargaan Aktif) 
Berdasarkan perhitungan diatas dapat disampaikan bahwa angka $\mathrm{R}$ sebesar 0,437 menunjukkan bahwa korelasi/hubungan antara variabel $x$ dengan variabel $y$ adalah lemah, karena angka ini berada di bawah 0,5. Angka R square menunjukkan koefisien determinasi. Besar R square adalah 0,191. Hal ini berarti 19,1\% perubahan variabel ydisebabkan oleh perubahan variabel $x$ sedangkan sisanya $80,9 \%$ disebabkan oleh faktor di luar perubahan variabel $x$. Angka $\mathrm{R}$ square yang dipakai karena jumlah variabel tidak lebih dari 2. Jika lebih dari 2 maka yang dipakai adalah Adjusted R square. Berdasarkan hal tersebut diatas, dapat disimpulkan bahwa Variabel x (Kecerdasan Media) berpengaruh signifikan terhadap variabel y (Kewargaan Aktif). Ini berarti bahwa semakin tinggi x (Kecerdasan Media), maka semakin tinggi pula y (Kewargaan Aktif). Hasil ini pararel dengan media habit responden yang mampu memilih dan memilah program siaran atau rubrik yang dapat memberikan manfaat sosial dalam rangka melaksanakan kewajiban sebagai warga negara. Mayoritas responden lebih memilih rubrik sosial politik pada media cetak yang mereka baca daripada gosip yang biasanya disukai remaja. Hal yang sama juga berlalu untuk pilihan program siaran baik di radio maupun televisi; kebanyakan responden lebih acara pemberitaan yang biasanya menanyangkan isu-isu terkini permasalahan publik yang berdampak langsung terhadap kehidupan bangsa.

Dari pembahasan diatas dapat disimpulkan beberapa hal sebagai berikut :

1. Kecakapan media (media literacy) berpengaruh secara signifikan terhadap terbangunnya kewargaan aktif (Active Citizenship) di kalangan siswa SMA Widyagama dan SMKN 4 Kota Malang.

2. Kecapakan media para responden dapat dilihat dari media habit yang mereka miliki; mereka telah mampu memilih dan memilih rubrik media cetak dan program siaran pemberitaan sosial politik yang lebih mengetengahkan permasalahan publik.

3. Para responden rata-rata memiliki kemampuan mengakses, menganalisis, mengevaluasi serta mencipta yang cukup significan. Demikian juga halnya dengan skor kewargaan aktif, para responden memiliki kemampuan yang cukup tinggi pula.

Berdasarkan simpulan di atas dapat disarankan beberapa hal:

1. Pentingnya kecapakan media (media literacy) sebagai sebuah ketrampilan untuk menunjang perilaku berbangsa dan bernegara dalam rangka menumbuhkembangkan proses demokratisasi bangsa yang sedang berjalan saat ini. Ketrampilan ini dapat 
diintegrasikan dalam satu mata pelajaran tertentu seperti Pendidikan dan Kewarganegaraan.

2. Kecakapan ini seperti juga perlu diberikan kepada para orangtua siswa sehingga mereka dapat memperkuat ketrampilan tersebut sehingga perilaku mengkonsumsi media dapat dijadikan sebagai bahan diskusi dalam lingkup keluarga. 



\section{Daftar Pustaka}

Baran, Stanley J., Davis, Dennis K., 2003, Mass Communication Theory: Foundations, Ferment, and Future, 6th Edition, Wadsworth Thomson Learning, Ontario, Canada

Buckingham, David., \& Sefton, Julian., 2001, Multi Media Education; Media Literacy in the Age of Digital Culture, dalam Rubert Kubey., 2001, Media Literacy in the Information Age: Current Perspectives, New Brunswick, New Jersey, USA

Center for Media Literacy, 2003, Media Literacy Kit : Teachers/ Leaders Orientation Guide, Center for Media Literacy, Santa Monica, Canada

Croteau, David \& Hoynes, William, 2001, The Business of Media : Corporate Media and the Public Interest, Pine Forge Press, California, Amerika Serikat

Frau-Meigs, Divina., 2006, Media Education : A Kit for Teachers, Students, Parents and Professional, UNESCO, Paris

Gazali, Effendi, Menayang, Victor et.al (ed)., (2003), Konstruksi Sosial Dunia Penyiaran: Plus Acuan Tentang Penyiaran Publik dan Komunitas, Departemen Ilmu Komunikasi FISIP, Universitas Indonesia, Jakarta.

Gans, Herbert J., 2003, Democracy and the News, Oxford University Press, New York, USA

Hobbs, Renee, 1998, Building Citizenship Skills through Media Literacy Education, In M. Salvador and P. Sias, (Eds.) The Public Voice in a Democracy at Risk. Westport, CT: Praeger Press, pps. 57 -76. Diakses pada http://www.medialit.org/reading$\underline{\text { room/building-citizenship-skills-through-media-literacy-education\#bio }}$

Jolls, Tessa., 2008, Literacy for the $21^{\text {st }}$ Century : An Overview \& Orientation Guide To Media Literacy Education, (2nd Edition) Featuring CML's Five Key Questions for both Construction and Deconstruction Questions/Tips (Q/TIPS), diakses pada http://medialit.org/pdf/mlk/ola_mlkorientation_rev2.pdf

Jhally, Sut \& Lewis, Justin., 1998, The Struggle for Media Literacy, Journal of Communication, Winter,1998 Vol 45, diakses dari https://mdlab2014.files.wordpress.com/2014/08/joc.pdf

Kovach, Bill dan Rosenstiel ,Tom, 2004, Sembilan Elemen Jurnalistik, Pantau, Jakarta

Kubey, Rubert., 2001, Media Literacy in the Information Age: Current Perspectives, New Brunswick, New Jersey, USA

Masterman, Len., 2001, A Rationale for Media Literacy, dalam Rubert Kubey., 2001, Media Literacy in the Information Age: Current Perspectives, New Brunswick, New Jersey, USA

Mc Chesney, Robert, 1997, Corporate Media and the Threat to Democracy, Seven Stories, New York, USA, diterjemahkan oleh Andi Ahdian, 1998, Konglomerasi Media 
Ancaman Bagi Demokrasi, Aliansi Jurnalis Independen (AJI), Jakarta.

McInerney, Chris., 2004, Civic Education: Practical Guidance Note, United Nations Development Programme (UNDP) Bureau for Development Policy - Democratic Governance Group, Oslo Governance Centre, diakses pada http://www.undp.org/governance/docs/A2I_Guides_Civic\%20education.pdf

Mc Nair, Brian, 1999, An Introduction to Political Communication, Routledge, New York, United State of America

Riisgaard Pedersen, Katrine, 2006, Mobilizing Poor People for Active Citizenship, UNDP, Paris

Potter, James W., 2001, Media Literacy, Sage Publication, California, USA

Sudibyo, Agus, (2004), Ekonomi Politik Media Penyiaran, LKIS, Yogyakarta.

Swestin , Grace, 2004, Reality Show: Wacana Pembodohan, Jurnal Media Watch, edisi 39Tahun IV-Agustus 2004, Lembaga Konsumen Media, Surabaya

Veldhuis, Ruud., 2005, Opportunities For Education And Learning For Active Citizenship,

Institute of Public Participation, Civitas International Steering Committee member, Nederland, diakses pada http://llw.acs.si/ac/09/cd/full_papers_plenary/Veldhuis.pdf 